\title{
Globalization and Malnutrition: Geographical Perspectives on Its Paradoxes
}

\author{
Elizabeth Young
}

\begin{abstract}
This chapter maintains that the food system is one of the most important globally embedded networks of production and consumption; its integral connections with the petroleum industry and global security confirm its significance. The chapter establishes the complex nature of mapping and measuring malnutrition. It reviews significant shifts in the incidence of malnutrition but argues that disaggregating statistics is vital to understanding trends. Changes in theorizations of the problem of malnutrition and associated solutions are then considered, including conceptual shifts from food security to food sovereignty. The global food chain is embedded in contentious political, economic, and scientific debates. Volatility in local food prices are influenced by global factors: oil prices; energy policies; dietary changes, foreign direct investments associated with "land grabs" or financial speculation. The chapter concludes with a call for a fundamental rethinking of global food provisioning to establish a more socially equitable and environmentally sustainable system.
\end{abstract}

Keywords Global food system - Geography of malnutrition - Conceptualization malnutrition - Mapping and measuring malnutrition - Food security • Food sovereignty • Politics and malnutrition - Food provisioning

The current food system has evolved in response to specific historical, political, and economic circumstances; it is not a natural system but a socially constructed one which reflects patterns of power and privilege. It is a dynamic system which has changed dramatically in the past and will in the future (Rosegrant et al. 2012). Goodman and Sage (2013) assert that "there is almost nothing more geographical than food in the ways that it intimately interlinks production and consumption, nature and society, bodies and landscapes, the global and the local, and indeed spaces, places, and everywhere in between" (p. 3). This chapter maintains that the

\footnotetext{
E. Young $(\bowtie)$

School of Sciences (Geography and Environment), Staffordshire University, Leek Road, Stoke-on-Trent ST4 2DF, UK

e-mail: 1.young@staffs.ac.uk

(C) The Author(s) 2016

P. Jackson et al. (eds.), Eating, Drinking: Surviving,

SpringerBriefs in Global Understanding, DOI 10.1007/978-3-319-42468-2_2
} 
food system has become one of the most important globally embedded networks of production and consumption; its integral connections with the petroleum industry and global security only serve to confirm its centrality and significance (Le Billon et al. 2014a, b; Goodall 2008; Weis 2009).

Geographical perspectives on food illuminate a cruel paradox at the heart of contemporary globalization. Why do millions of people still die from hunger and hunger-related diseases while the health of millions is threatened by an obesity pandemic? In a world where millions enjoy a more varied diet than ever before and waste nearly as much as they eat, why does food scarcity still haunt millions? Meanwhile countries as varied as China, Mexico, Saudi Arabia, and Egypt now suffer a "double burden" where under nutrition coexists with obesity as a major public health problem; a strange world too where "some people destroy food because prices are too low, and others literally eat dirt because food prices are too high" (Angus 2008: 1). Understanding these paradoxes requires analysis of unprecedented changes in global food provisioning in the last 40 years, but we start with a review of malnutrition statistics which establishes the contentious nature of the "food debate."

[A]bout 805 million people are estimated to be chronically undernourished in 2012-14, down more than 100 million over the last decade......In the same period, the prevalence of undernourishment has fallen from 18.7 to 11.3 percent globally (SOFI, 2014 introduction).

So, time to celebrate? Maybe, but first it is vital to consider some problems associated with measuring malnutrition (Lappé et al. 2013; IFPRI 2014). The FAO (2012, 2014) employs a limited definition of hunger based on a diet of 1800 kilocalories per day, the minimum for someone who is not active. If we assume people are active and need more calories, then these estimates are a gross underrepresentation. They also ignore "hidden hunger," diets sufficient in calories but which lack essential minerals and vitamins, such as iron, vitamin A, iodine and zinc. A recent estimate holds that 2 billion people suffer from this form of malnutrition and associated health problems (IFPRI 2014, p. 5).

Such statistics also ignore the geography of global hunger. While there has been a marked decline in under nutrition between 1990 and 2014, the process has been very uneven. Advances "by two countries, China ( -96 million) and Viet Nam ( -24 million) amounts to $91 \%$ of the net numerical reduction in undernourished people between 1990 and 2012" (Lappé et al. 2013, p. 1). Such geographical disaggregation is vital for understanding global trends. It is also vital for identifying successful and unsuccessful national policies. Examining regional trends is complex too-examples from Africa exemplify this point.

The 2012 FAO Report remarks that "we are losing the battle in Africa." However, if we disaggregate the statistics, a more nuanced picture emerges; countries in this region exemplify best and worst practice. Ghana's success is dramatic and illustrates what can be done to reduce hunger by dedicated political interventions (Curtis 2011). In contrast, the Democratic Republic of Congo exemplifies the worst case situation and helps explain the poor performance of Sub Saharan Africa (SSA) in aggregate; extract this one country and the "picture" from 
SSA is less depressing. These examples exemplify the importance of scale to analyses of malnutrition; it is always instructive to disaggregate data whether at the global, regional or national scale.

Disaggregating statistics based on other variables is also illuminating, as populations which are economically and political marginalized dominate national statistics. Rural populations have a higher incidence of malnutrition than urban populations; females and children more than males; ethnic minorities and people with disabilities more than the general population (Young 2012). Finally, world food prices are volatile and subject to changes associated with social and natural factors, so numbers vary seasonally and the specific geography of their impacts are notoriously complex (Cohen and Smale 2012).

Recently malnutrition due to overconsumption has emerged, diets with too many calories, sugar, and fats are a major global public health problem. Once considered a problem for small numbers of people in affluent societies, obesity has now reached epidemic proportions. ${ }^{1}$ Globalization since the 1970 s helps explain the nutritional transition in the global south and the emergence of obesity there (Hawkes 2006). Countries formerly concerned only with under nutrition now suffer from a 'double burden' where under nutrition coexists with obesity (FAO 2006). Alarming headlines appear regularly across the globe, there is no escape from the "obesity pandemic" (Popkin 2007; Frenk 2012). However, measuring obesity is problematic and its incidence, as well as its implications, is contested. The discussion above establishes the controversial and contentious nature of mapping and measuring malnutrition; explaining the causes and evaluating solutions are more politically charged, it is indeed a "battle for mouths, minds and markets" (Lang and Heasman 2004). How do we explain the patterns of malnutrition and how may they be reduced?

Proximate factors may be responsible for volatile food prices and increases in the number of hungry people, but the nature of these has changed markedly as the food system has become more global in character. In the past, unpredictable weather, pests and conflict often resulted in local food price increases and associated food shortages. Today, local food prices are more often influenced by global factors: oil prices; energy policies; dietary changes, foreign direct investments associated with "land grabs" or financial speculation (Saturnino et al. 2011; Goodall 2008; Geary 2012; GRAIN 2008; IATP 2008; Ghosh 2009; Jarosz 2009; Wahl 2009; Swaminathan 2013). To understand the extensive and protracted nature of global malnutrition we must examine the profound changes in the structure and nature of global political economy (Clapp 2012; Clapp and Cohen 2009; von Braun 2007; Weis 2007; Young 2012; Le Billion et al. 2014a, b; McMichael 2009; Magdoff 2004, 2008, 2013; Magdoff and Tokar 2010).

Conceptualisations of the problem and their associated policy recommendations are diametrically opposed and reflect divergent political perspectives. At one

\footnotetext{
${ }^{1}$ Describing obesity as an 'epidemic' is controversial as, unlike most epidemics, it is not a communicable disease.
} 
extreme are those who advocate more industrial food production and urge us to embrace new technologies emerging from corporate research laboratories. This vision triumphs the technological revolution that has transformed agricultural production since the end of the 1950s and argues that the revolution should be extended and intensified (World Bank 2008; Beddington 2010; DuPont 2014; Monsanto 2014). This perspective employs a narrow interpretation of food security:

food security, at the individual, household, national, regional and global levels is achieved when all people, at all times, have physical and economic access to sufficient, safe and nutritious food to meet their dietary needs and food preferences for an active and healthy life (World Food Summit 1996).

Traditional approaches have emphasized producing more food from a more or less stable resource base, a process sometimes referred to as 'sustainable intensification'. But transformations of the global system over the last 60 years mean that the food security concept has limited purchase to tackle the myriad problems associated with the food system today; namely, human rights abuses, international trade and aid policy, global governance and development policy, equity, access and ownership of resources, public health, and environmental issues, for example (Pretty et al. 2010; Sage 2012; Mittal 2009; Young 2010; Carolan 2011). Conceptualizing 'the food problem' as a simple 'production' issue, where 'we need more food' ignores the complex reasons that some people are hungry. This 'productionist' approach still dominates debates about the problem of hunger and is allied to Malthusian interpretations where "too many people" are understood to be the problem. Such simplistic interpretations are untenable; the problem is much more complex and politically charged. As Maxwell and Slater (2004, p. 3) conclude '[A] preoccupation with food security is no longer sufficient'.

At the other end of the spectrum, are those who argue that the nature of contemporary food production is the cause of the current crisis and that its promotion will exacerbate the problem (Wise and Sundell 2014). This vision calls for a fundamental rethinking of global food provisioning, and argues for changes at every stage of the food system to establish a more socially equitable and environmentally sustainable system (Clapp 2012; Paarlberg 2010; Thurow and Kilman 2009; von Braun 2007; Weis 2007; Lang and Heasman 2004; Holt-Gimenez and Patel 2009; Young 2012). This interpretation emphasizes the central role of corporate control and the political manipulation of trade and subsidy regimes. At present corporate profits increase while millions remain hungry, others become obese and the environment suffers. World Watch (2010) suggest that instead of producing more food a more effective way to address food security issues and climate change would be to encourage self-sufficiency and waste reduction, in wealthier and poorer nations alike. Such perspectives reject the narratives emanating from agribusiness interests and their allies in governments; instead they emphasize securing "entitlements" and promoting "food sovereignty" (see Bartos, this volume).

Sen (1981) introduced the concept of entitlements and transformed the debate about food security and hunger. He argued that "[S]tarvation is the characteristic of some people not having enough food to eat. It is not the characteristic of there not 
being enough food to eat" (Sen 1981, p. 1); as is the case today when we produce more than enough food to feed everyone. However, millions do not have the capacity to access the food in their midst, their assets (financial and social) are insecure or minimal; food follows customers, whether people or pets. Processes operating at every scale influence how food is distributed and how entitlements are constructed (Young 2012, p. 22). The ability of some people to command food reflects their political, economic, or social status. The role of gender is an obvious example; female entitlements are frequently constrained by discrimination which privileges male access to land, capital, and education (Action Aid 2010; IFAD 2012; Tsikata and Golah 2010; IDS 2014; FAO 2013).

Food sovereignty (Nyelini Declaration 2007) is another concept employed to explain malnutrition; it draws attention to how and where decisions about the food system are implemented. Unlike food security, it puts the question of power and politics at the center of the debate (Schanbacher 2010). Food sovereignty "is the right of peoples to healthy and culturally appropriate food produced through ecologically sound and sustainable methods, and their right to define their own food and agriculture systems" (Nyeleni Declaration). The concept has been adopted by myriad groups who want radical changes to the contemporary food system (Anderson and Bellows 2012; GRAIN 2014). ${ }^{2}$ Major themes include: securing livelihoods; gender equity; environmental objectives; land and property rights and agrarian reform policies; local autonomy; democratic systems of governance; and it urges resistance to corporate control of the food system. Food sovereignty establishes politics at the heart of the food debate. It is about who controls the food system and about human rights (Valente 2014). This perspective challenges the power of corporations, other special interests and the institutions of global governance (World Trade Organization, World Bank and International Monetary Fund) that deliver their agendas. Instead, they demand that the food system be more democratically governed and locally embedded; for them, neo-liberal, market-based solutions - hegemonic since the 1950s - are not working and business as usual is not an option (Wise 2013).

Every stage of the modern food chain is embedded in contentious economic and scientific debates; these are political because they are about the role of markets and the state, about global trading regimes and the ability of governments to control their agricultural and food policies. They are political because food security is the most basic expectation that citizens have of their government; failure to provide a decent diet is associated with autocratic or corrupt regimes or conflict ridden political situations. Finally, they are political because scarcity leads to food riots which have been associated with radical regime change in the past and food is now embedded in global security debates.

Given the complexity of the food system, employing various scales for analysis helps illuminate some otherwise obscure interactions. Processes which operate at

\footnotetext{
${ }^{2}$ The right to adequate food and freedom from hunger is also inscribed in international law through Article 11.2 of the 1966 International Covenant on Economic, Social, and Cultural Rights.
} 
the global scale are mediated by national processes and these, in turn, are modified by a variety of internal variables. Global processes establish the context within which national processes operate and create distinctive national geographies of food production and consumption (Wise and Murphy 2012). The limitations of national analyses are obvious; however, most of us still consume our food in national contexts and, rightly or wrongly, still presume that national governments can intervene to improve food provisioning systems or the nature of our diets. Then local and household variables further help explain entitlements, culturally and regionally specific variables generate local diversity. Clearly there are multiple political spaces where challenges to the contemporary food system and its socially and environmentally unsustainable character can be resisted. Realizing alternative visions will require vigorous political activism by diverse interests at global, national and local scales (Sage 2013, 2014; Horlings and Marsden 2011). Positive changes have been detailed, their implementation is urgent (Wise and Murphy 2012). The political landscapes of agriculture and food are changing and one might ask whether, as the main players of the past (USA and EU) are replaced by the emerging agricultural giants, namely, Brazil, China and India, will this herald a new more equitable vision for global food security?

\section{References}

Action Aid (2010) Her mile: Women's rights and access to land. http://www.landcoalition.org/en/ publications/her-mile-women\%E2\%80\%99s-rights-and-access-land. Accessed 8 January 2015 at $17.11 \mathrm{GNT}$.

Anderson, M. D., \& Bellows, A.(2012) Introduction to symposium on food sovereignty: Expanding the analysis and application. Food Sovereignty 29(2), 177-184.

Angus, I. (2008). 'Food crisis: The greatest demonstration of the historical failure of the capitalist model' global research. http://www.socialistvoice.ca/?p=274. Accessed 7 January 2015.

Beddington, J. (2010) Global food and farming futures. Philosophical Transactions Royal Society B 265, 2767.

Carolan, M (2011) The real cost of cheap food. London: Routledge.

Clapp, J. (2012). Food. Cambridge: Polity Press.

Clapp, J., \& Cohen, M. (Eds) (2009). The global food crisis: Governance challenges and opportunities (pp. 1-12). Canada: The Centre for International Governance Innovation and Wilfrid Laurier University Press.

Cohen, M. J., \& Smale, M. (2012). Global food-price shocks and poor people: Themes and case studies. Oxon: Routledge.

Curtis, M. (2011). Country successes in reducing hunger: How they did it, and why other donors and governments should change policy. http://www.actionaid.org/sites/files/actionaid/country_ successes_in_reducing_hunger_mark_curtis_nov_2011_0.pdf. Accessed 6 January 2015.

DuPont. (2014). Food solutions. http://www.dupont.com/corporate-functions/our-approach/globalchallenges/food.html. Accessed 19 November 2014.

Food and Agricultural Organization. (2006). The double burden of malnutrition: Case studies from six developing countries. Rome: FAO.

Food and Agricultural Organization. (2012). State of food insecurity in the world. http://www.fao. org/docrep/016/i3027e/i3027e00.htm. Accessed 8 January 2015. 
Food and Agricultural Organization. (2013). Gender equality and food security: Women's empowerment as a tool against hunger. http://www.fao.org/wairdocs/ar259e/ar259e.pdf. Accessed 9 January 2015.

Food and Agricultural Organization. (2014). State of food insecurity in the world. http://www.fao. org/3/a-i4030e.pdf. Accessed 8 January 12015.

Frenk D. J. (2012). The obesity prevention source globalization. http://www.hsph.harvard.edu/ obesity-prevention-source/obesity-causes/globalization-and-obesity/. Accessed 9 January 2015.

Geary, K. (2012) Our Land, Our Lives: Time out on the global land rush. Oxfam Briefing Paper. http://policy-practice.oxfam.org.uk/publications/our-land-our-lives-time-out-on-the-globalland-rush-246731. Accessed 9 December 2014.

Ghosh, J. (2009). The unnatural coupling: Food and global finance. Journal of Agrarian Change, $10(1), 72-86$.

Goodall, C. (2008) Burning food: Why oil is the real villain in the food crisis. Guardian, May 30th

Goodman, M., \& Sage, C. (2013) Food transgressions: Ethics, governance and geographies. Environment, Politics and Development Working Paper Series Department of Geography, King's College London No 52. http://www.kcl.ac.uk/sspp/departments/geography/research/ epd/GoodmanSageWP52.pdf Accessed 9 December 2014.

GRAIN. (2008). Seized. The 2008 land grab for food and financial security briefings. October http://www.grain.org/article/entries/93-seized-the-2008-landgrab-for-food-and-financialsecurity. Accessed 8 January 2015.

GRAIN. (2014). Food sovereignty: 5 steps to cool the world and feed its people. http://www.grain. org/article/entries/5102-food-sovereignty-5-steps-to-cool-the-planet-and-feed-its-people. Accessed 9 January 2015.

Hawkes, C. (2006) Uneven dietary development: Linking the policies and processes of globalization with the nutrition transition, obesity and diet-related chronic diseases. Globalization and Health 2. http://www.globalizationandhealth.com/content/2/1/4. Accessed 9 January 2015.

Holt-Gimenez, E., \& Patel, R. (2009). Food rebellions: Crisis and the hunger for justice. Oxford: Fatamu Books.

Horlings, L. G., \& Marsden T. K. (2011). To-wards the real green revolution? Exploring the conceptual dimensions of a new ecological modernisation of agriculture that could feed the world. Global Environmental Change 21, 441-452.

Institute of Development Studies. (2014). Gender and food security: Towards gender-just food and nutrition security. http://bridge.ids.ac.uk/ids-document/A69889?lang=en\#lang-pane-en. Accessed 3 December 2014.

IATP. (2008). Commodities market speculation: The risk to food security and agriculture. http:// www.iatp.org/files/451_2_104414.pdf. Accessed 4 January 2015.

International Fund for Agricultural Development IFAD. (2012). Gender equality and female empowerment: Policy. http://www.ifad.org/gender/policy/gender_e.pdf. Accessed 6 January 2015.

International Food Policy Research Institute. (2014). Global nutrition report. http://www.ifpri.org/ publication/global-nutrition-report-2014.Accessed 24 November 2014.

Jarosz, L. (2009). Energy, climate change, meat and markets: Mapping the coordinates of the current world food crisis. Geography Compass, 3, 2065-2083.

Lappé, F. M., Clapp, J., \& Wise, T. (2013) Framing hunger: A response to the state of food insecurity in the world 2012. Cambridge: Small Planet Institute. http://www.ase.tufts.edu/gdae/ Pubs/rp/FramingHunger.pdf?u=74907371d448da77287940e4d\&id=0f773fe487\&e= c42ae444af. Accessed 28 October 2014 at 12.23.

Le Billon, P., Sommerville M., \& Essex J. (2014a). Introduction: Global food crisis. Geopolitics 19(2), 235-238

Le Billon, P., Sommerville, M., \& Essex, J. (2014). The 'global food crisis' and the geopolitics of food security. Geopolitics, 19(2), 239-265. 
Lang, T., \& Heasman, M. (2004). Food wars: The global battle for mouths, minds and markets. London: Earthscan.

Magdoff, F. (2004). A precarious existence: The fate of billions?. http://www.monthlyreview.org/ 0204magdoff.htm. Accessed 12 November 2009.

Magdoff, F. (2008). The world food crisis: Sources and solutions. Monthly Review. http://www. monthlyreview.org/080501magdoff.php. Accessed 12 November 2009.

Magdoff, F. (2013) Twenty-first-century land grabs: Accumulation by agricultural dispossession. Monthly Review. http://monthlyreview.org/2013/11/01/twenty-first-century-land-grabs/. Accessed 7 January 2015.

Magdoff, F., \& Tokar B. (Eds) (2010). Agriculture and food in crisis: Conflict, resistance and renewal. New York: Monthly Review Books.

Maxwell, S., \& Slater, R. (2004). Food policy old and new. In S. Maxwell \& R. Slater (Eds.), Food policy old and new. Oxford: Overseas Development Institute, Blackwell Publishing.

McMichael, P. (2009). A food regime analysis of the world food crisis. Agriculture Human Values, 26, 281-295.

Mittal, A. (2009).The blame game; Understanding the structural causes of the food crisis. In J. Clapp \& M. J. Cohen ibid., (pp. 13-28).

Monsanto. (2014). Producing more. http://www.monsanto.com/improvingagriculture/pages/ producing-more.aspx. Accessed 19 November 2014.

Nyeleni Declaration (2007) http://nyeleni.org/spip.php?article290. Accessed 7 January 2015.

Paarlberg, R. L. (2010). Food politics: What everyone needs to know. Oxford: Oxford University Press.

Pretty, J. et.al. (2010). The top 100 questions of importance to the future of global agriculture. International Journal of Agricultural sustainability 8(4), 220-236.

Popkin, B. M. (2007). The world is fat. Scientific American, 297, 88-95.

Rosegrant, M. W., Tokgoz, S., Bhandary, P., \& Msangi, S. (2012) Looking ahead: Scenarios for the future of food. International Food Policy Research Institute. http://www.ifpri.org/ publication/2012-global-food-policy-report?print. Accessed 29 October, 2014 at 12.27.

Sage, C. (2012). Addressing the Faustian bargain of the modern food system: Connecting sustainable agriculture with sustainable consumption. International Journal of Agricultural Sustainability 10(3), 204-207.

Sage, C. (2013). The inter-connected challenges for food security from a food regimes perspective: Energy, climate and malconsumption. Journal of Rural Studies, 29(1), 71-80.

Sage, C. (2014). The transition movement and food sovereignty: From local resilience to global engagement in food system transformation. Journal of Consumer Culture 14(2), 254-275.

Saturnino Jr. M. B., Hall, R., Scoones I., White, B., \& Wolford, W. (2011). Towards a better understanding of global land grabbing: An editorial introduction. The Journal of Peasant Studies 38(2), 209-216.

Schanbacher, W. D. (2010). The politics of food: The global conflict between food security and food sovereignty. Santa Barbara: Praeger.

Sen, A. (1981). Poverty and famine: An essay on poverty and deprivation. Oxford: Clarendon Press.

Swaminathan, M. S. (2013). Biofuels and food security. http://www.fao.org/fileadmin/user_ upload/hlpe/hlpe_documents/HLPE_Reports/HLPE-Report-5_Biofuels_and_food_security.pdf. Accessed 9 December 2014.

Thurow, R., \& Kilman, S. (2009). Enough: Why the world's poorest starve in a world of plenty. New York: Public Affairs.

Tsikata, D., \& Golah, P. (Eds) (2010). Land tenure, gender and globalisation: Research and analysis from Asia, Africa and Latin America. Ottawa: International Development Research. http://www.idrc.ca/EN/Resources/Publications/openebooks/463-5/index.html. Accessed 6 January 2015.

Valente, F. L. S. (2014). Towards the full realisation of the human right to adequate food and nutrition. Right to Food Journal 9(1). http://www.fian.org/fileadmin/media/publications/Right_ to_Food_Journal_2014_web.pdf. Accessed 7 January 2015. 
Von Braun, J., \& Díaz-Bonilla, E. (Eds.) (2007). Globalization of food and agriculture and the poor. New Delhi: Oxford UniversityPress.

Wahl, P. (2009). Food speculation: The main factor of the price bubble in 2008. Berlin, Germany: World Economy, Ecology \& Development.

Weis, T. (2007). The global food economy: The battle for the future of farming. London: Zed Books.

Weis, T. (2009). Fossil energy and biophysical roots of the food crisis. In J. Clapp \& M. J Cohen ibid. (pp. 145-160).

Wise, T. (2013). Can we feed the world in 2050? A scoping paper to assess the evidence. GDAE Working Paper No. 13-04, September 2013. http://www.ase.tufts.edu/gdae/policy_research/ FeedWorld2050.html

Wise, T., \& Murphy, S. (2012). Resolving the food crisis: Assessing global food policy reforms since 2007. Institute for Agriculture and Trade Policy (IATP) and Global Development and Environment Institute (GDAE). http://www.ase.tufts.edu/gdae/Pubs/rp/ResolvingFoodCrisis. pdf

Wise, T., \& Sundell, K. (2014) To feed the world in 2015 we have to change course. Accessed 6 Jan 2015. http://foodtank.com/news/2014/10/to-feed-the-world-in-2050-we-have-to-changecourse

World Food Summit. (1996). Rome Declaration on World Food Security.

World Bank Development Report. (2008). Agriculture for development. Washington: World Bank. World Watch. (2010). State of the world 2011 innovations that nourish the planet. http://www. worldwatch.org/system/files/NtP-Innovations-in-Action.pdf. Accessed 8 January 2015.

Young, E. M. (2010) Deadly diets. Geography 95(part 2), 60-69.

Young, E. M. (2012) Food and development. London: Routledge.

Open Access This chapter is distributed under the terms of the Creative Commons Attribution 4.0 International License (http://creativecommons.org/licenses/by/4.0/), which permits use, duplication, adaptation, distribution and reproduction in any medium or format, as long as you give appropriate credit to the original author(s) and the source, provide a link to the Creative Commons license and any changes made are indicated.

The images or other third party material in this chapter are included in the work's Creative Commons license, unless indicated otherwise in the credit line; if such material is not included in the work's Creative Commons license and the respective action is not permitted by statutory regulation, users will need to obtain permission from the license holder to duplicate, adapt or reproduce the material.

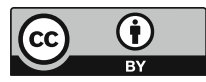




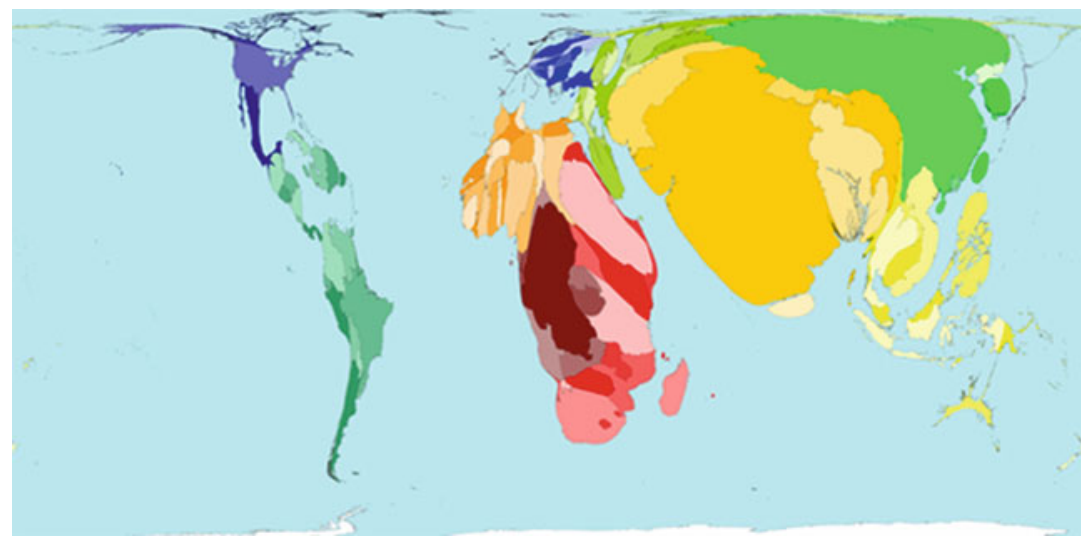

Undernourishment. Over the ten year period from 1990 to 2000, the number of people in the world that lived on an inadequate amount of food increased from 840 to 858 million. Due to the population increases over this period, the percentage of the population that is undernourished simultaneously decreased from 16 to $14 \%$. Territory size shows the proportion of all undernourished people worldwide, that live there. Source www.worldmapper.org. Published with kind permission of (C) Copyright Benjamin D. Hennig (Worldmapper Project)

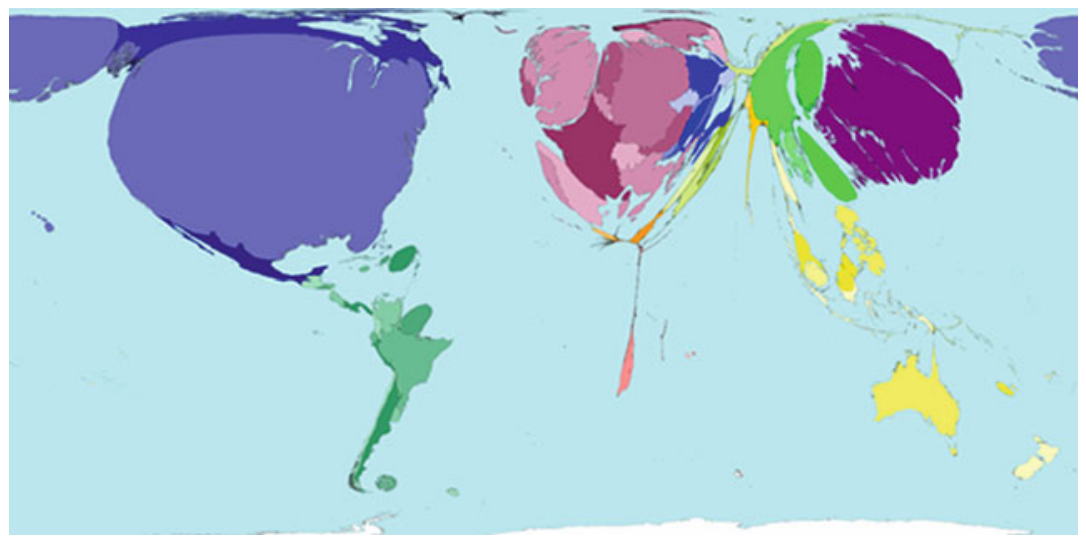

International fast food. This map shows the distribution of one major brand of fast food outlet, $45 \%$ of which were located within the United States. The next highest number of these outlets was in Japan, Canada and Germany. Territory size shows the proportion of all McDonalds restaurants that were open in 2004, that were found there. Source www.worldmapper.org. Published with kind permission of (C) Copyright Benjamin D. Hennig (Worldmapper Project) 